\title{
Evaluation of forensic cases admitted to pediatric intensive care unit
}

\author{
Burcu Bursal Duramaz¹, Hamdi Murat Yıldırım², Hasan Serdar Kıhtır², Osman Yeşilbaş², Esra Şevketoğlu² \\ ${ }^{1}$ Clinic of Pediatrics, Bakırköy Dr. Sadi Konuk Training and Research Hospital, İstanbul, Turkey \\ ${ }^{2}$ Pediatric Intensive Care Unit, Bakırköy Dr. Sadi Konuk Training and Research Hospital, İstanbul, Turkey
}

\begin{abstract}
Aim: This study aimed to determine the epidemiological and clinical characteristics of pediatric forensic cases to contribute to the literature and to preventive health care services.

Material and Methods: Pediatric forensic cases hospitalized in our pediatric intensive care unit below the age of 17 years were reviewed retrospectively (January 2009June 2014). The patients were evaluated in two groups as physical traumas (Group A) and poisonings (Group B). The patients' age, gender, complaints at presentation, time of presentation and referral (season, time) and, mortality rates were determined. Cases of physical trauma (Group A) were classified as traffic accidents, falling down from height, falling of device, drowning, electric shock, burns and child abuse. Poisonings (Group B) were classified as pharmaceuticals, pesticides, other chemicals and unknown drug poisonings.

Results: Two hundred twenthy cases were included. The mean age was 5.1+3.1 years. One hundred fifteen (\%52.5) of the cases were male and 105 (\%47.5) were female. Group A consisted of 62 patients and Group B consisted of 158 patients. The patients presented most frequently in summer months. The most common reason for presentation was falling down from height (12.7\%) in Group A and accidental drug poisoning (most frequently antidepressants) in Group B. The mortality rate was $5 \%$.

Conclusion: Forensic cases in the pediatric population (physical trauma and poisoning) are preventable health problems. Especially, preventive approach to improve the environment for falling down from height must be a priority. Increasing the awareness of families and the community on this issue, in summer months during which forensic cases are observed most frequently can contribute to a reduction in the number of cases. (Turk Pediatri Ars 2015; 50: 145-50)

Keywords: Forensic case, trauma, poisoning
\end{abstract}

\section{Introduction}

Forensic cases are defined as events which generally occur as a result of carelessness and imprudence, which may have an objective of murder or suicide and which lead to disruption in the physical and psychological integrity of the individual or to death (1). Firearm, explosive substance and sharp object injuries, traffic accidents, battery (physical violence), falls, occupational accidents, drug, food and substance poisonings, burns, electric shocks and lightning strikes, asphyxia, claims of torture and maltreatment, suicide attempts and deaths which are suspected to be due to murder, suicide and accidents in the childhood are defined as forensic cases (2).
The initial presentation, investigations, diagnosis and treatment in forensic cases occur in emergency departments. The patients who are referred to universities or tertiary care hospitals for the aim of further investigations and treatment constitute a significant portion of presentations at emergency departments and have higher morbidity and mortality rates (3).

In our study, it was aimed to retrospectively determine the epidemiological and clinical characteristics of pediatric forensic cases hospitalized in our pediatric intensive care unit, to contribute to the literature in this area, to determine what actions can be taken in the name of preventive healthcare services and to take prospective measures. 


\section{Material and Methods}

The pediatric intensive care unit of our hospital has been giving service to patients aged between one month and 17 years who need advanced intensive care with nine beds for ten years. The patients aged below 17 years who were hospitalized in our unit between January 2009 and June 2014 and were defined to be forensic cases were examined retrospectively by way of medical files and forensic report recordings. Two hundred twenty patients who were considered to be forensic cases with completed medical records hospitalized and treated in the pediatric intensive care unit were included in the study. Four patients whose medical recordings were deficient were excluded from the study.

The cases included in the study were divided into two groups as physical traumas and poisonings. Cases of physical trauma (Group A) were grouped as traffic accidents, falling down from height, falling down of equipment, drowning, electric shock, burns and child abuse. Poisoning cases (Group B) were grouped as pharmaceuticals, pesticides (organophosphates and other insecticides), other chemicals and unknown drug poisonings. The ages, gender, reason of presentation, time of presentation (season, time) and mortality rates of the patients were determined.

\section{Statistical analysis}

Statistical analysis was performed using NCSS (Number Cruncher Statistical System) 2007 Statistical Software (Utah, USA) package program.
In assessment of the data, independent $t$ test was used in comparison of the variables which showed a normal distribution, Mann Whitney U test was used in comparison of the variables which did not show a normal distribution, chi-square and Fischer's exact test were used in comparison of the qualitative variables in addition to descriptive statistical methods (mean, standard deviation). A $p$ value of $<0.05$ was considered significant.

\section{Results}

Group A was composed of 62 patients (28.18\%) and Group B was composed of 158 patients (71.82\%) (Table 1). One hundred fifteen (52.5\%) of the patients were male and 105 (47,5\%) were female. The number of the male patients in Group A was significantly higher compared to the female patients (p:0.01). The mean age of the patients was $5.1 \pm 3.7$ years ( $4.5 \pm 3$ in boys and $5.8 \pm 4.3$ in girls). The mean age was $5.4 \pm 3.5$ years in Group $A$ and $5 \pm 3.8$ years in Group B. No statistically significant difference was found between the two groups in terms of age.

The patients were divided into five groups as one monthtwo years (62; $28.18 \%)$, three-six years $(116 ; 52.72 \%)$, seven-ten years $(14 ; 6.36 \%), 11-13$ years $(15 ; 6.81 \%)$ and $14-17$ years $(13 ; 5.9 \%)$ for convenience in statistical assessments (Figure 1). Fifty tree percent of the patients were in the three-six-year age group.

The period during which presentations occurred most frequently was found to be the summer (73 patients; $33.3 \%)$. It was observed that patients presented at daytime more frequently (116 patients; $52.7 \%$ ), though not statistically significantly (Table 1 ).

Table 1. Demographic properties of the subjects

\begin{tabular}{|c|c|c|c|c|c|c|}
\hline \multirow{2}{*}{ Age (years) } & & \multicolumn{2}{|c|}{ Group A (n:62) } & \multicolumn{2}{|c|}{ Group B (n:158) } & $\mathrm{p}$ \\
\hline & & \multicolumn{2}{|c|}{$5.41 \pm 3.57$} & \multicolumn{2}{|c|}{$5.07 \pm 3.80$} & $0.482^{*}$ \\
\hline \multicolumn{2}{|c|}{ Time until presentation (hours) } & \multicolumn{2}{|c|}{$4.67 \pm 3.22$} & \multicolumn{2}{|c|}{$4.42 \pm 2.47$} & 0.543 \\
\hline \multicolumn{2}{|c|}{ Duration of hospitalization (days) } & \multicolumn{2}{|c|}{$8.76 \pm 11.07$} & \multicolumn{2}{|c|}{$2.69 \pm 1.90$} & $0.0001^{\star}$ \\
\hline \multirow[t]{2}{*}{ Gender } & Male & 41 & $66.10 \%$ & 74 & $46.80 \%$ & \multirow{2}{*}{$0.01^{\star \star}$} \\
\hline & Female & 21 & $33.90 \%$ & 84 & $53.20 \%$ & \\
\hline \multirow[t]{4}{*}{ Season } & Winter & 9 & $14.52 \%$ & 30 & $18.99 \%$ & \multirow{4}{*}{0.379} \\
\hline & Spring & 13 & $20.97 \%$ & 37 & $23.42 \%$ & \\
\hline & Summer & 26 & $41.94 \%$ & 47 & $29.75 \%$ & \\
\hline & Fall & 14 & $22.58 \%$ & 44 & $27.85 \%$ & \\
\hline \multirow{3}{*}{$\begin{array}{l}\text { Time of presentation } \\
\text { (hours) }\end{array}$} & Daytime & 25 & $40.32 \%$ & 91 & $57.59 \%$ & \\
\hline & Evening & 24 & $38.71 \%$ & 46 & $29.11 \%$ & \multirow[t]{2}{*}{0.064} \\
\hline & Night & 13 & $20.97 \%$ & 21 & $13.29 \%$ & \\
\hline \multicolumn{2}{|l|}{ Mortality } & 9 & $14.52 \%$ & 2 & $1.27 \%$ & 0.0001 \\
\hline \multicolumn{7}{|l|}{ *Mann Whitney U } \\
\hline
\end{tabular}


The most common reason of presentation in the patients in group A was falling down from height (39 patients; $62.9 \%$ ). Thirteen patients presented because of traffic accident (20.9\%), four patients presented because of drowning (6.4\%), two patients presented because of electric shock (3.2\%), two patients presented because of falling down of equipment (3.2\%), one patient presented because of burn (1.6\%) and one patient presented because of sodomy (1.6\%) (Table 2 ).

The most common reason of presentation in Group B was accidental substance ingestion (146 patients; 92.5\%) and 12 patients presented with suicide (7.5\%). The substances ingested accidentally included antidepressants, unknown drugs, paracetamol, chemical substances (thinner, acetone, cologne, napthaline, gas oil, ethyl alcohol, ink, cyanide and mushroom poisoning), cardiovascular drugs, salbutamol, antipsychotics, muscle relaxants, hormone derivatives, insecticides, colchicine, nonsteroid anti-inflammatory drugs (NSAI), organophosphates, antiepileptics and decongestants, respectively. The drugs which were ingested intentionally for the aim of suicide included unknown and multiple drugs, antidepressants,

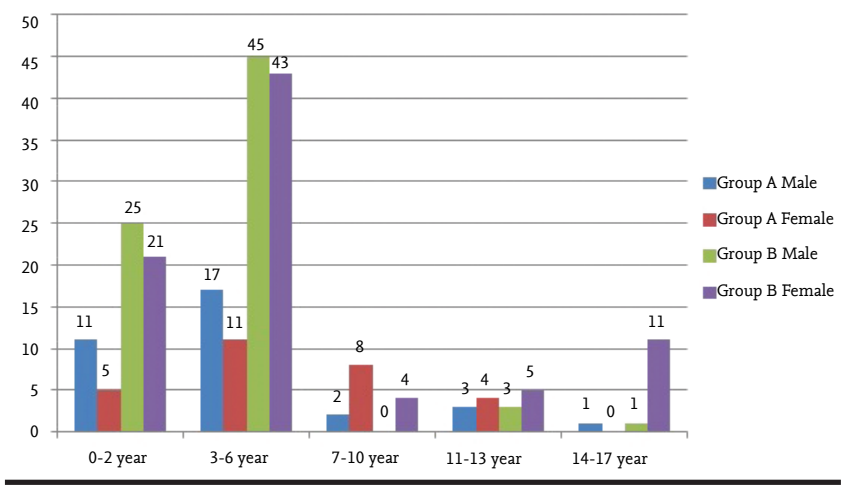

Figure 1. Distribution of the number of patients by age

Table 2. Distribution of the cases of physical trauma

\begin{tabular}{lccc}
\hline & $\mathrm{n}$ & \%* & \%** \\
\hline Falling down from height & 39 & 62.9 & 17.73 \\
Non-vehicle traffic accident & 9 & 14.51 & 4.09 \\
In-vehicle traffic accident & 4 & 6.45 & 1.82 \\
Drowning & 4 & 6.45 & 1.82 \\
Falling down of equipment & 2 & 3.22 & 0.91 \\
Electric shock & 2 & 3.22 & 0.91 \\
Burn & 1 & 1.61 & 0.45 \\
Sodomy & 1 & 1.61 & 0.45 \\
Total & 62 & 100 & 28.18 \\
\hline
\end{tabular}

*In-group percentage distributions of the subjects

**Percentage distributions of the subjects in the study group colchicines, antipsychotic drugs, cardiovascular drugs and NSAI, respectively (Table 3). Suicide attempt was found in 12 patients (5.45\%). Suicide was significantly more frequent in girls ( 11 girls, one boy) (p:0.002). The mean age of the girls who attempted suicide was 14.2 years.

The duration of hospitalization was found to be $8.76 \pm 11.07$ days in Group A and $2.69 \pm 1.90$ days in Group $\mathrm{B}$ and there was a statistically significant difference between the two groups (p:0.0001). The mortality rate was found to be $5 \%$ in the patients who were hospitalized in the pediatric intensive care unit in accordance with the definition of forensic case. Nine patients in Group A and two patients in group B were lost. Seven of the patients who were lost were male and four were female.

\section{Discussion}

Studies related with forensic cases in the literature mostly examine presentations at pediatric emergency outpatient clinics (2-8). In our study, forensic cases followed up in the pediatric intensive care unit were analyzed in contrast to the literature. Since our study was the first study (as far as we know) conducted with forensic cases followed up in pediatric intensive care units, the comparisons were made with the studies conducted in pediatric emergency outpatient clinics.

Table 3. Distribution of the cases of poisoning

\begin{tabular}{lccc}
\hline & $\mathrm{n}$ & $\% \star \star$ & $\% \star \star \star$ \\
\hline Antidepressant & 28 & 16.37 & 12.73 \\
Unknown drug & 20 & 11.69 & 9.09 \\
Paracetamol & 19 & 11.11 & 8.64 \\
Chemical & 17 & 9.94 & 7.73 \\
Cardiovascular drugs & 14 & 8.18 & 6.36 \\
Salbutamol & 11 & 6.43 & 5 \\
Antipsychotics & 11 & 6.43 & 5 \\
Muscle relaxants & 10 & 5.84 & 4.55 \\
Hormones & 8 & 4.67 & 3.64 \\
Insecticides & 8 & 4.67 & 3.64 \\
Colchicine & 7 & 4.09 & 3.18 \\
Organophosphate & 7 & 4.09 & 3.18 \\
Nonsteroid anti-inflammatory drugs & 7 & 4.09 & 3.18 \\
Antiepleptics & 3 & 1.75 & 1.36 \\
Decongestants & 1 & 0.58 & 0.45 \\
Total & $171 *$ & 100 & 71.82 \\
\hline *The non-traumatic group included 158 patients and the total number was calculated \\
to be 17l, because some patients ingested multiple drugs & & \\
$\star *$ In-group percentage distributions of the subjects & & \\
***Percentage distributions of the subjects in the study group & \\
\hline
\end{tabular}


In our study, the number of male patients was found to be significantly higher compared to the number of female patients in Group A. It was thought that the possibility of trauma was increased in boys, because they spent more time outside home and were supervised to a lesser extent by their parents compared to girls.

In a study conducted in our country, 486 pediatric forensic cases presented to a tertiary care emergency department ( $\leq 17$ years) were evaluated. It was found that the mean age of the patients was $8.91 \pm 5.08$ and most (66.3\%) were male and the number of patients in the five-nineyear age group was higher compared to the other age groups (2). In another study, the mean age in the forensic cases in the childhood age group who presented to emergency department was found to be $8.8 \pm 4.37$ years. In the same study, it was found that children in the 7-10year age group presented most frequently and $66 \%$ of the patients were male (4). In our study, the mean age was lower compared to the above mentioned studies. Fifty three percent of our patients were in the three-sixyear age group. This suggested that younger children were a more risky group in terms of physical trauma or poisoning, they might show more severe clinical findings and need intensive care more frequently.

In many studies, it has been found that forensic cases most commonly present in the summer months $(2,3$, 5-7). In our study, it was also observed that presentations increased in the summer months, though statistically insignificantly.

The most common reason of presentation in cases of poisoning was found to be accidental ingestion of substances which was compatible with the literature (2). In cases of physical trauma, the most common reason of presentation was found to be falling down from height. This was found to be compatible with two studies conducted previously in the Aegean region and Central Anatolia $(8,9)$. However, falling down from height was in the fourth row and the most common reason was reported to be traffic accidents in a study which examined four-year data from the Marmara region (10).

Suicide is the third leading cause of death in the young ones aged between 15 and 24 years in USA and approximately two million adolescents attempt suicide each year (11). It was found that children and adolescents constituted $24.4 \%$ of all legal autopsies performed because of suicide between 1997 and 2005 in the Southern region of Turkey (12). It was found that the reason was suicide in $13.4 \%$ of the deaths below the age of 18 years. It was reported that girls predominated (62.9\%) among the cases of suicide and the mean age was 16.1 years (12). Generally, high dose and multiple drug ingestion are noted in cases of suicide. In our study, suicide attempt was found in 12 patients (5.45\%) and 11 of the patients were female. The mean age of the girls who presented with suicide attempt in our study was lower compared to the study reported above. Suicide attempts closely concern pediatricians, psychiatrists and parents. A better communication of adolescent girls with their parents within the family, expression of emotions and thoughts easily and guidance of adolescents without engaging in conflict with them should be encouraged.

According to the "Centers for disease Control and Prevention" (CDC) data, approximately two thirds of all deaths in children and adolescents between the ages of five and 19 years are related with reasons including motor vehicle accidents, unintentional injuries, murder and suicide attempt (13). It is predicted that $90 \%$ of unintentional injuries can be prevented with education of parents and simple measures (14).

In this study, the mortality rate was found to be $5 \%$ (seven boys and four girls). The highest mortality rate was observed in the cases of falling from height (five patients; three boys, two girls). This was followed by non-vehicle traffic accident, ingestion of unknown drug and falling down of equipment. When the data related with 72 deaths which occurred as a result of external causes between 1977 and 2004 in young children below the age of four years in Sweden were examined, it was found that 15 (21\%) occurred as a result of crashing of motor vehicles and 14 (19\%) occurred as a result of in-vehicle accidents. In twelve children (17\%), the reason was found to be intentional assault (15). When all injuries-deaths between the ages of zero and 17 years between 2000 and 2006 in San Diego County, California were examined, it was found that 884 legal medical examinations was performed and death occurred because of unnatural reasons in 480 of these. It was found that most of the subjects were male (68.3\%) and the most common reason of death was traffic accidents. This was followed by asphyxia (22.7\%) and sharp object injuries (17.7\%). Forty one percent of the deaths occurred at the crime scene, $35.5 \%$ occurred on the way and $28 \%$ occurred at home (16). In our study, the excess of the cases of falling from height was noted. When this subject was examined, it was observed that protective safety precautions for children at doors and windows in environments where children are found were legally mandatory in developed countries (17). We think that this kind of measures should also be taken rapidly in our country and compliance of parents with applications related with window safety will decrease the mortality to a great extent. 
In many studies, it has been reported that clearance of the gastrointestinal system constitutes the most important part of treatment in pediatric patients who present at emergency departments because of acute poisonings. Toxic substances in the gastrointestinal system can be removed with emesis, gastric lavage, administration of active charcoal, cathartics, intestinal lavage, plasmapheresis, peritoneal dialysis and hemodialysis. However, use of active charcoal has predominated instead of emesis and gastric lavage in recent years (1820). In our study, 114 patients (51.8\%) were given active charcoal and gastric lavage was administered in $115 \mathrm{pa}-$ tients (52.2\%) after consulting with the National Posion Information Center (NPIC). Gastric lavages and administration of active charcoal were performed based on the recommendations of the NPIC by indication. Rapid transfer of patients to emergency departments after the event plays an important role in success of treatment in cases of poisoning. Our patients presented to emergency departments in a mean time of $4.5 \pm 2.7$ hours and were hospitalized in the PICU. Our study is compatible with the literature in this regard $(21,22)$. The duration of hospitalization was found to be $8.76 \pm 11.07$ days in group A and $2.69 \pm 1.90$ days in group B. A statistically significant difference was found between the groups in terms of hospitalization period (p:0.0001). This may be explained with the fact that patients with physical trauma were hospitalized for a longer time in proportion with the severity of trauma.

Deaths arising from poisonings have decreased because of more safe packaging, increased education directed to prevent poisoning and developments in medical treatment (23). In USA, the mortality rate was reported to be 0,008 according to 1993 data (18). Andiran et al. (21) reported the mortality rate to be $0.4 \%$ and Bekdaş et al., (24) found the mortality rate to be $0,38 \%$. In our study, two patients (1.27\%) lost their lives because of poisoning. These patients were lost as a result of multi-organ failure following ingestion of multiple and unknown medications. The high mortality rates of ours may be related with the fact that we follow up high risk patients in our pediatric intensive care unit.

Generally, drugs and substances used at home are reported as a cause of poisoning. Among drugs, analgesics are in the first row and this is followed by drugs which are used frequently and thus left around including central nervous system drugs and cardiac drugs $(18,19,22$, $24,25)$. In our study, antidepressants were in the first row, unknown drugs were in the second row and paracetamol was in the third row. These drugs were followed by chemical substances (thinner, acetone, cologne, nap- thaline, gas oil, ethyl alcohol, ink, cyanide and mushroom poisoning). Antidepressants are being used more frequently in the community (26). It should be predicted that the patients who use antidepressants may not be able to keep the drugs away from children. It can be thought that this may explain the increase in the number of antidepressant drug poisonings. We think that presentation and packaging of antidepressant drugs in such a way that children cannot open them may decrease the number of poisonings.

In the study of Leventhal et al. (27) published in 2012, all patients below the age of 18 years hospitalized in 2006 in USA were examined and it was found that 4569 patients were hospitalized because of child abuse and 300 of these resulted in mortality. In one study conducted in Turkey, the rate of presentation because of child abuse among forensic cases below the age of 17 years was found to be $0.8 \%$. In this study, the authors drew attention to the low number of cases of child abuse found in the records among forensic cases (2). In our study, it was found that there was no case of child neglect, domestic violence or Munchausen by proxy syndrome and there was only one case of sodomy when the forensic cases were examined. This suggested that physicians avoided questioning these areas in detail while taking history or families did not give accurate information.

The majority of the cases of physical trauma and poisoning which are considered forensic cases in the childhood are preventable health problems. The most efficient approach is to establish a safe environment for children. We think that protective safety precautions for children at doors and windows in environments where children are found should be legally mandatory to prevent falling down form height and education of parents in this area should be addressed primarily.

Children should be prevented from reaching drugs to decrease the frequency of childhood poisonings. Drugs should not be prepared in forms and colors which will draw the attention of children and a safe environment should be established for children, namely, drugs should be kept in locked cupboards and out of reach of children. Visual and written campaigns should be arranged to inform the community. Continuous health education should be given to parents and children throughout the year emphasizing that these events can increase in the summer months.

Special attention should be given to adolescent girls to determine suicide tendency at an early time in this age group and emotional problems including introversion, 
personality crisis, avoiding people, sense of emptiness, boredom and tiredness which may occur during this period should be emphasized. It is important to present a loving environment and sharing to this age group, make them feel valuable and give them the opportunity to solve their problems. Parents should be told that they should refer to child psychiatrists when they fall short in solving problems.

Ethics Committee Approval: Ethics committee approval was received for this study from the ethics committee of Bakırköy Dr. Sadi Konuk Educational and Research Hospital (14.07.2014/147).

Informed Consent: Written informed consent was not obtained from patients due to the retrospective nature of this study.

Peer-review: Externally peer-reviewed.

Author Contributions: Concept - B.B.D.; Design - B.B.D. H.M.Y.; Supervision - B.B.D., E.Ş.; Funding - B.B.D., H.S.K.; Materials - B.B.D., O.Y.; Data Collection and/or Processing - B.B.D.; Analysis and/or Interpretation - H.M.Y.; Literature Review - B.B.D., H.S.K.; Writer B.B.D.; Critical Review - E.Ş.

Conflict of Interest: No conflict of interest was declared by the authors.

Financial Disclosure: The authors declared that this study has received no financial support.

\section{References}

1. Kök AN, Öztürk S, Tunalı İ. Yatarak tedavi gören 959 adli vakanın retrospektif değerlendirilmesi. Adli Tıp Dergisi 1992; 8: 93-8.

2. Sever M, Saz EU, Koşargelir M. An evaluation of the pediatric medico-legal admissions to a tertiary hospital emergency department. Ulus Travma Acil Cerrahi Derg 2010; 16: 260-7.

3. Akoğlu H, Denizbaşı A, Ünlüier E, Güneysel Ö, Onur Ö. Marmara Üniversitesi Hastanesi acil servisine başvuran travma hastaların demografik özellikleri. Marmara Medical Journal 2005; 18: 113-22.

4. Demir ÖF, Aydın K, Turan F, Yurtseven A, Erbil B, Gülalp B. Acil servise başvuran çocuk adli olguların analizi. Türk Ped Arş 2013; 235-40.

5. Küçüker $\mathrm{H}$. Acil servise gelen ölümle sonuçlanmayan travmatik adli olguların ve raporların değerlendirilmesi. Acil Tıp Dergisi 2003; 17: 47-53.

6. Türkmen N, Akgöz S, Çoltu A, Ergin N. Uludağ Üniversitesi Tıp Fakültesi acil servisine başvuran olguların değerlendirilmesi. Uludağ Üniv Tıp Fak Derg 2005; 31: 25-9.

7. Turla A, Aydın B. Ondokuz Mayı Üniversitesi Tıp Fakültesine başvuran adli nitelikli çocuk olguların değerlendirilmesi. Adli Tip Bülteni 2007; 12: 106-11.

8. Gül M. Epidemiological analysis of trauma cases applying to emergency department. Selçuk Üniversitesi Tıp Fak Derg 2003; 19: 33-6.
9. Pekdemir M, Cete Y, Eray O, Atilla R, Çevik AA, Topuzoğlu A. Epidemiological characteristics of trauma patients. Ulus Travma Derg 2000; 6: 250-4.

10. Dalkılıç G, Öncel M, Acar H, Topsakal M, Olcay E. The presentation of surgicial emergency policlinic patients for four years. Ulus Travma Acil Cerrahi Derg 1998; 4: 17-422.

11. Kennedy SP, Baraff LJ, Suddath RL, Asarnow JR. Emergency department management of suicidal adolescents. Ann Emerg Med 2004; 43: 452-60. [CrossRef]

12. Arslan M, Akcan R, Hilal A, Batuk H, Çekin N. Suicide among children and adolescents: data from Çukurova, Turkey. Child Psychiatry Hum Dev 2007; 38: 271-7. [CrossRef]

13. Centers for Disease Control and Prevention. School health guidelines to prevent unintentional injuries and violence. MMWR Recomm Rep 2001; 50: 1-73.

14. Feury KJ. Injury prevention. Where are the resources? Orthop Nurs 2003; 22: 124-30. [CrossRef]

15. Bjornstig U, Bjornstig J, Ahlm K, Sjogren H, Eriksson A. Violent deaths in small children in northern Sweden. Int J Circumpolar Health 2006; 65: 28-34. [CrossRef]

16. Fraga AM, Fraga GP, Stanley C, Costantini TW, Coimbra R. Children at danger: injury fatalities among children in San Diego County. Eur J Epidemiol 2010; 25: 211-7. [CrossRef]

17. Pressley JC, Barlow B. Child and adolescent injury as a result of falls from buildings and structures." Injury Prevention 2005; 11: 267-73. [CrossRef]

18. Rodgers G. Poisonings: drugs, chemicals and plants. In: Behrman RE, Kliegmen RM, Jenson HB, (eds). Nelson Textbook of Pediatrics. $16^{\text {th }}$ ed. Philadelphia: WB. Saunders Company, 2000: 2160-3.

19. Uzel N. Zehirlenmeler. İçinde: Neyzi O, Ertuğrul T, (yazarlar). Pediatri Cilt 2, 3. bask. İstanbul: Nobel Tip Kitabevi, 2002: 1527-67.

20. Sarıkayalar F. Çocuklarda zehirlenmeler. Katkı Pediatri Derg 2001; 22: 377-95.

21. Andıran N, Sarıkayalar F. İhsan Doğramacı Çocuk Hastanesinde son altı yılda izlenen akut zehirlenmeler. Katkı Pediatri Derg 2001; 22: 396-407.

22. Ertekin V, Altınkaynak S, Alp H, Yiğit H. Çocukluk çağında zehirlenmeler: son 3 yıldaki vakaların değerlendirilmesi. Çocuk Dergisi 2001; 1: 104-9.

23. Fortenberry JD. General Principles of Poisonings. In: Crocetti M, Barone AM, Oski FA, (eds). Oski's essential pediatrics. 2nd ed. Philadelphia: J.B. Lippincott Company 2004: 216-21.

24. Bekdaş M, Atakan C, Kapuağası A. Hastanemize başvuran zehirlenme vakalarının değerlendirilmesi. Yeni Tıp Dergisi 2000; 17: 78-80.

25. Ergür AT, Sütçü İ, Tanzer F. Pediatri servisimizdeki zehirlenme olgularının değerlendirilmesi 1990-1998. Türkiye Klinikleri J Pediatr 1999; 8: 9-13.

26. Pratt Laura A, Debra JB, Qiuping G. Antidepressant use in persons aged 12 and over: United States, 2005-2008. NCHS Data Brief 2011; 76: 1-7.

27. Leventhal JM, Martin KD, Gaither JR. Using US data to estimate the incidence of serious physical abuse in children. Pediatrics 2012; 129: 458-64. [CrossRef] 